\title{
Effects of VAT reduction and increase in minimum salary in the northern border of Mexico (Baja California)
}

\section{Efectos de la reducción del IVA y el aumento del salario mínimo en la frontera norte de México (Baja California)}

TORRES-GÓNGORA, María de Jesús †*, CAREY, Carmen, CASTRO, Claudia and PORY, Aurora

Instituto Tecnológico de Tijuana

ID $1^{\text {st }}$ Author: María de Jesús, Torres-Góngora

ID $1^{\text {st }}$ Coauthor: Carmen, Carey

ID $2^{\text {nd }}$ Coauthor: Claudia, Castro

ID $3^{\text {rd }}$ Coauthor: Aurora, Pory

DOI: $10.35429 / J L E .2019 .5 .3 .14 .20$

Received August 15, 2019; Accepted December 20, 2019

\begin{abstract}
The objective of this article is to examine some of the immediate effects observed in the companies of Baja California before the 50 percent decrease in the value added tax (VAT) and the increase to the minimum wage of 100 percent. A survey was conducted with businessmen from various sectors to get their opinion on tax and income changes, while reviewing the data presented in the National Employment Occupation Survey for workers who received a minimum wage in the last half of the year 2018 and the first half of the year 2019 by size of establishment.
\end{abstract}

Northern border of Mexico, Tax Reform, minimum wage, Value Added Tax (VAT)

\section{Resumen}

El objetivo de este artículo es examinar algunos de los efectos inmediatos observados en las empresas de Baja California ante la disminución del 50 por ciento en el impuesto al valor agregado (IVA) y el aumento al salario mínimo del 100 por ciento. Se realizó un sondeo con empresarios de diversos sectores para conocer su opinión sobre los cambios fiscales y de ingreso, a la vez que se revisaron los datos presentados en la Encuesta Nacional de Ocupación Empleo para trabajadores que recibían salario mínimo en la última mitad del año 2018 y la primera mitad del año 2019 por tamaño de establecimiento.

Frontera Norte de México, Reforma Fiscal, Salario mínimo, Impuesto al Valor Agregado (IVA)

Citation: TORRES-GÓNGORA, María de Jesús, CAREY, Carmen, CASTRO, Claudia and PORY, Aurora. Effects of VAT reduction and increase in minimum salary in the northern border of Mexico (Baja California). Journal-Law and Economy. 2019. 3-5: 14-20.

\footnotetext{
* Correspondence to Author (email: maria.torres@tectijuana.edu.mx)

$\dagger$ Researcher contributing as first author.
} 


\section{Introduction}

With the double increase of the minimum wage on the northern border of Mexico and the decrease in Value Added Tax (VAT) at the beginning of the year 2019, it was expected that there would be an increase in the real income of workers, a smaller impact is observed in the companies since many by own decision or for not being able to accede to the decree continued charging $16 \%$ of the VAT.

On this occasion, the contrast between the responses obtained through a survey of twenty local businessmen and managers with the results of the first data reported by the National Occupation and Employment Survey (ENOE) is presented. The results obtained outline an improvement for those employees who received less than two minimum wages that is not significant in terms of the macroeconomic results of the announced average.

The following article is presented within the activities carried out at the Technological Institute of Tijuana as part of the Observatory of the new fiscal and income conditions for the border strip that includes the municipality of Tijuana and Playas de Rosarito where it is intended to account for the immediate effects due to the reduction of VAT and the increase in the minimum wage as of January 1, 2019.

\section{Methodology}

Because it is an unprecedented change of two macroeconomic variables, it was necessary to approach the phenomenon from a qualitative perspective that would allow us to know the reactions of the local business community, together with the fact that in the first months there were no reliable data on the effects of the change in VAT and minimum wage.

Therefore, a survey was carried out by applying a questionnaire to a directed sample of twenty entrepreneurs, who were asked about their expectations and strategies to deal with the changes, since a VAT reduction was supposed to represent a reduction in their expenses and an increase in its sales due to the reduction in prices while the increase in the minimum wage constituted an increase in its production costs.
On the other hand, the data of the National Survey of Occupation and Employment (ENOE) was analyzed, disaggregating at the state level and separating by salary, level of education and size of establishment to observe in which strata the increase in the minimum wage has had greater impact and contrast it with what is expressed in the questionnaire by the businessmen.
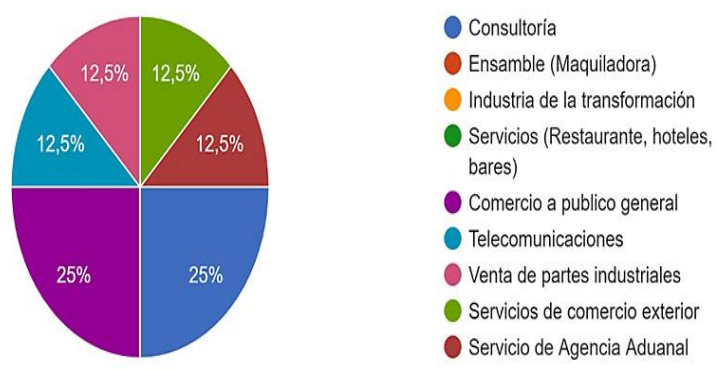

Figure 1 Turn of the companies of the businessmen and managers who responded to the survey.

Source: own elaboration.

\section{Effects of the VAT decrease from $16 \%$ to $8 \%$ in Baja California.}

Mexico for incentive purposes and fiscal policies has been divided into regions and zones, where we find the municipalities of Tijuana and Playas de Rosarito that was called zone I. This section of the border region between California (USA) and Baja California (Mexico) shares economic ties and historical-geographical neighborhood relations, on the one hand California is the state with the largest population in the United States has approximately 39,000,000 inhabitants and the third in territorial extension California contributes with 13 percent of the GDP of the States United has given rise to a great industrial, commercial and technological development whereby the state alone acquires international relevance. On the other hand, Baja California according to 2010 census data had 3,600,000 inhabitants, which represented 3 percent of the total population in Mexico and contributes to the country's GDP with 2.8 percent. Approximately $84 \%$ of the population in the border area is urban and is concentrated in three cities that house 80 percent of the population. Ciudad Juarez in the state of Chihuahua and Tijuana in Baja California on the other hand San Diego is the richest county in the southern border of the United States with approximately 40 percent of the population of the U.S. border. 
Hence the importance of the Tijuana-San Diego region compared to the rest of the great border that these two countries share. Baja California in turn is the point that connects Mexico with a globalized world where not only competing with traditional forms of production, but with high standards from international companies that locate parts of their production between the two borders.

The northern border region of Mexico has faced differentiated fiscal policies from the rest of the country due to the special conditions of neighborhood with the United States. The local businessmen grouped in the different business chambers have sought the restoration of the so-called border free zone with which the State had before the six-year term of Miguel de la Madrid without much success. The free zone was eliminated with the support of Mexican President Carlos Salinas de Gortari. During the six-year terms of the presidents Vicente Fox, Felipe Calderón and Enrique Peña, the law was modified to standardize the fiscal conditions of the border to those of the rest of the country, including eliminating differentiated conditions for importation and increasing the value tax rate aggregate.

With the change of the President of Mexico in December 2018 and perhaps in response to the series of negotiations carried out in the framework of the renegotiation of the Free Trade Agreement between Mexico, the United States and Canada (NAFTA) and internal pressures for compliance with the campaign promises, the conditions for the border area changed radically at the beginning of the year 2019 at least on paper. The value-added tax was reduced from 16 percent to 8 percent through the "Northern Border Region Fiscal Stimulus Decree $8 \%$ VAT" while the minimum wage was doubled from $\$ 88.36$ to $\$ 176.72$ pesos.

\section{Fiscal Stimulus Decree Northern Border Region 8\% VAT}

The decree consists of applying in the Northern Border Region two tax credits, one over the Income Tax (ISR) equivalent to one third of the ISR caused in the year with respect to the rest of the country, with the condition that total revenues have been obtained in the border region and the other at $50 \%$ of the general VAT rate (8\%); fulfilling certain requirements established in the Decree for both stimuli.
Regarding the VAT issue, it was expected to be something very similar to what it has been in previous years, since the rate was differentiated in the border area. Rates of 3, 6, 10 and $11 \%$ already existed when in the rest of the country the rate was higher, the ISR was expected to fall from 30 to $20 \%$.

However, after the publication of the Decree, the businessmen realized that its application would not be generalized but that a series of requirements should be met to obtain the benefits offered, which in most cases are out of control. of the companies.

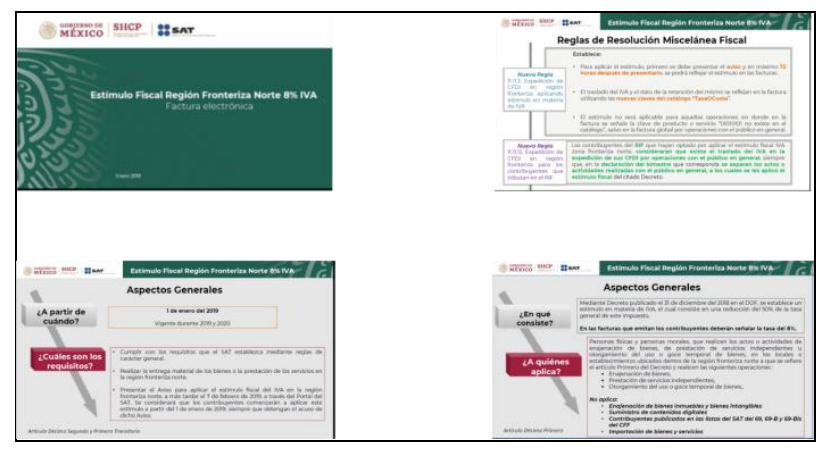

Figure 2 Presentation Material issue the electronic invoice according to the North Border Region Fiscal Stimulus 8\% VAT

Source: (Sistema de Administración Tributaria, 2019)

The announcement at the end of 2018 of the 50\% VAT reduction at the border caused great expectations in the region, which had more than 15 years asking the central government to grant fiscal conditions that would allow this part of the border to be competitive with the Southern United States As mentioned earlier, the reduction was not a benefit to which all companies, or all products, could access.

At the beginning there were few companies that were able to enroll in the VAT reduction program, excluding imported goods, companies with fiscal domiciles outside the indicated border strip, as well as those of recent creation. The complications and procedures involved in adhering to the collection of $8 \%$ VAT generated that, after the first term, extensions were opened seeking that the number of companies joined will increase. 
In a first survey applied in March to twenty local businessmen to the question about the benefits of the VAT reduction they were dissatisfied with the resolution, in the first place, because imported goods were excluded and their cash flow was already compromised that when marketing to buy imported or produced goods outside the border strip they had to pay $16 \%$ VAT and they had to charge $8 \%$ VAT to their customers within the border strip. There were doubts about the tax differential that the SAT resolved would remain as a balance in favor of the taxpayer. Such a condition impacted companies in their cash flow, becoming more evident in small and medium-sized businesses. By conditioning VAT on companies without a fiscal domicile in the area, many of the goods produced in other parts of the country did not adhere to the $8 \%$ decree and imported goods that represent a large part of the consumption of an average family were excluded from the decree There are few marketable products that could benefit, as well as those that do not cause VAT such as medicines and food. The businessmen consulted in the survey responded mostly that although they had done the corresponding procedures for the reduction of VAT, not all had obtained favorable responses and at the time of the survey they had not observed a reduction in their costs attributable to the VAT decrease.

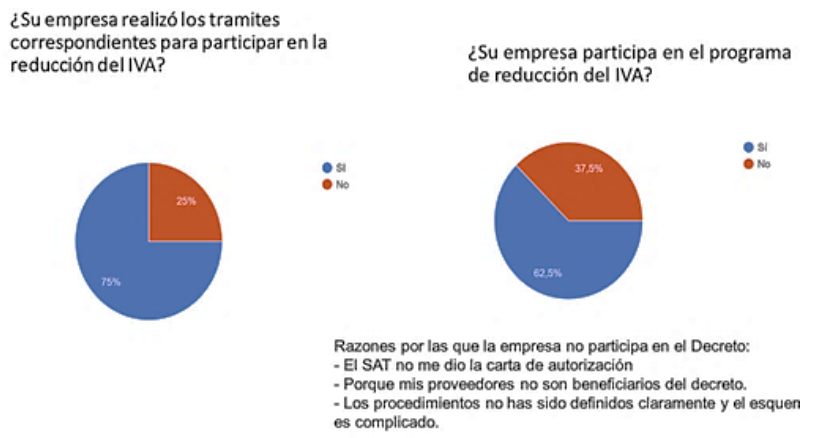

Figure 3 Companies that carried out the process for VAT reduction and those that benefited from said reduction

Among the expected effects with the application of the VAT reduction only for products made in the border area, it was that the local supply will increase due to the reduction of costs, however the total number of entrepreneurs and managers agreed that they would not change suppliers since in most cases there are no local companies or they do not have the certifications or standards requested by the clients of the firms that mostly compete in international markets.
The other expected effect would be the increase in disposable income in households given the reduction of VAT so far the aggregate data presented by the National Institute of Statistics and Geography (INEGI) do not show a greater commercial flow as a result of the decrease in VAT in the Tijuana region, Rosarito.

\section{Effects of the increase in the minimum wage in the border strip}

With respect to the minimum wage applicable to Tijuana and most of Baja California, it was within what was considered zone A since in Mexico there were minimum wage tabulators applied to different locations in Mexico; For 2019, the National Minimum Wages Commission (Conasami) determined the creation of a new wage economic zone for localities located on the border strip that generally includes 25 kilometers inland from the dividing line with the United States, for which established a general border minimum wage where without distinction of the activity to be carried out would be $\$ 176.72 \mathrm{mn}$

With regard to the differential of income of workers with a minimum wage in 2018 between the two border states, it was around 0.50 cents per hour in Tijuana versus 10 dollars per hour in San Diego. Situation that was evident in the renegotiation of the Free Trade Agreement with the United States and Canada, this differential being pointed out as one of the causes of the transfer of labor-intensive industries to this region of Mexico. It should be noted that in studies on salaries it was known that the average income of workers in Tijuana was around 3 minimum wages, on average 240 pesos a day (approximately 12 dollars, 1.5 dollars per hour).

One of the expected effects with a double increase in the minimum wage was that inflation in the region will increase, the Ministry of Economy Graciela Márquez Colín in interviews offered on the subject said that: (The increase in the minimum wage) "It will have positive effects on the purchasing power of workers and zero effects such as inflation or unemployment" 
In this regard, in the survey of businessmen, they were asked about the effects on their companies in the face of changes in income, to which some of the interviewees including small businessmen, accountants and employees report that "as already paid more than minimum they did not make changes" "they increased our salary and they took away benefits" "Now the operators earn the same as the supervisors ".
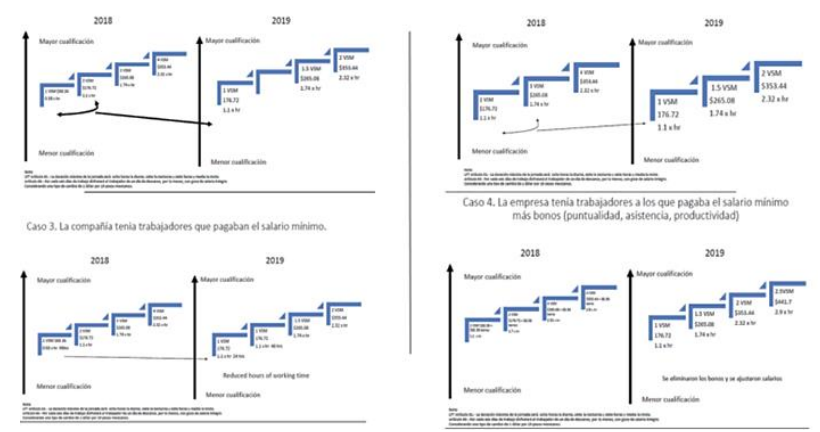

Figure 4 Comparison of four standard cases of the salary situation of workers in companies in the Tijuana-Playas de Rosarito area

Source: own elaboration with the scenarios proposed by the entrepreneurs in the survey carried out

When reviewing the sayings of the employers, it was found that in most companies only the income had changed for those workers who earned the minimum wage and that those who in 2018 received up to two minimum wages became workers of a salary minimum. In other cases, companies chose to eliminate the payment of bonuses to workers and integrate them into the minimum wage. The disagreement of the workers who received more than a minimum wage that did not see their income increased did not reach the levels of violence reached in the first months of 2019 in other parts of the border strip, especially the protests and strikes raised in Tamaulipas, although it was reflected in slight increases to the rest of the employees. The effects of the change in the minimum wage on workers were differentiated in terms of level of education and income, as well as the size of the establishment where they worked. According to the results presented in the National Survey of Occupation and Employment (ENOE), it can be observed that regardless of the level of schooling, workers who received up to a minimum wage and more increased, while there is a clear decrease in workers who receive more than two minimum wages and up to three.

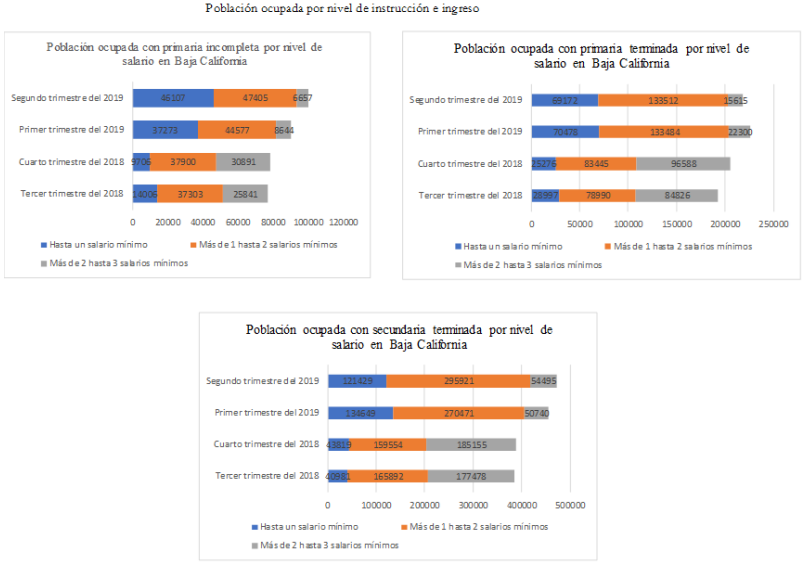

Figure 5 Population employed by level of education and income

Source: own elaboration with INEGI data. National Occupation and Employment Survey (ENOE)

The effects of the increase in the minimum wage were also observed in a differentiated way between the different establishment sizes, since most of the workers who received minimum wages worked in small and medium-sized establishments from which it can be inferred that it is these who faced a greater increase in its costs for labor. While the increase in the number of workers with minimum wages in 2019 is observed in large companies, which confirms what was said by employers in the survey, employees who received more than two minimum wages are now considered as minimum wages without this represents higher income for workers.

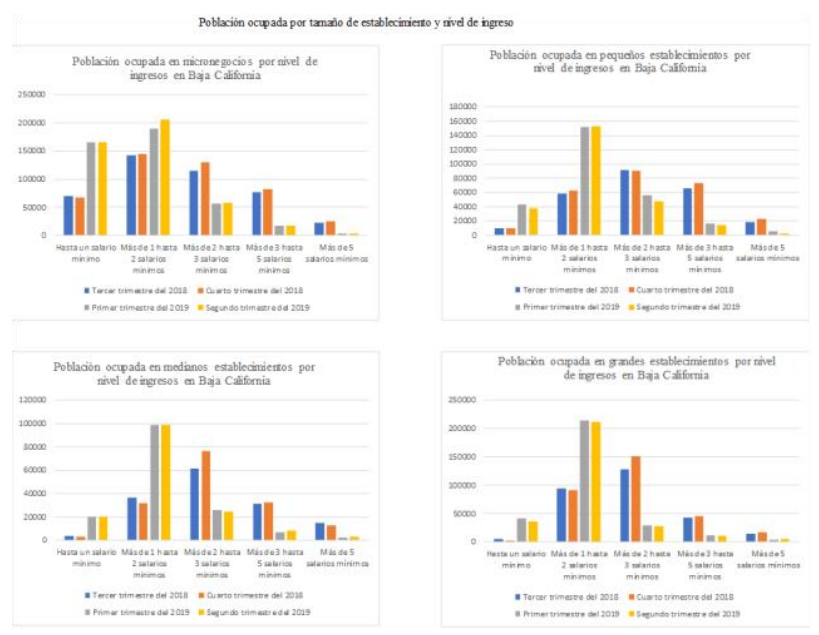

Figure 6 Population employed by size of establishment and income level

Source: own elaboration with INEGI data. National Occupation and Employment Survey 


\section{Conclusions}

After analyzing the data obtained so far for the part of the border area of Baja California, Mexico given the new fiscal and income conditions that it faces as of January 1, 2019, it was found that the VAT decrease as applied has not represented an increase in the level of real income, since most of the products that are consumed in the region or are imported or come from the rest of the country and these were not granted the decrease to $8 \%$, less families Income did not observe an increase in their level of real income from consumption, since a large part of their income goes to the purchase of food and medicines and these do not cause VAT in Mexico. With regard to companies, the effect was differentiated between small and mediumsized companies had difficulties to achieve their incorporation into the decree and in the subsequent derivative operation due to the VAT differentials between the purchase and sale that affected their income flow by what they chose to continue paying and charging 16\% VAT; while the large companies with greater access to groups of accountants and advisors were able to access said decree and compensate the differentials for the value added tax, so the department stores, automotive agencies granted their clients such decrease benefiting people of higher income.

With respect to the minimum wage increase of 100 percent, there are no macroeconomic data to consider whether the impact on inflation in the area was as expected. What can be observed is the impact on the income of workers, in this regard the National Commission for Minimum Wages in its report shows that "The results indicate that the increase in the minimum wage had no effect on the employment registered with the IMSS , that is, the average employment growth of the ZLFN is the same as in the counterfactual built with the information from the rest of the country, although they have had very different minimum wage increases. In the case of income per worker, the rise in the minimum wage had positive and significant effects. As a result of the increase, in the ZLFN workers in general earn $6.7 \%$ more than in the rest of the country. In the case of young people between 15 and 24 years old, the impact on the average salary was $9.2 \%$ " (www.gob.mx, 2019)
Although it seems that there was a benefit for those who received a minimum wage this was not significant since before the change there were very few workers in that condition. What is observed is that since there is no obligation to increase salaries for those workers who will earn more than $\$ 176.72 \mathrm{mn}$, the companies reduced benefits and adjusted the payroll, generating discomfort among the rest of the unfilled workers at the level of demonstrations and strikes from other areas of the border strip.

\section{Acknowledgments}

A special thanks to the Technological Institute of Tijuana for the support for the realization and consolidation of the Observatory of Fiscal and Entry Conditions in Zone I of the Northern Border of Mexico, as well as to the students of the Master in Administration of the same institute for their contributions and experience in the labor field. Thanks to the co-authored teachers of the present for their invaluable company and collaboration.

\section{References}

Diario Oficial de la Federación. (12 de junio de 2015). Ley Federal del Trabajo. Obtenido de https://www.gob.mx/cms/uploads/attachment/fi le/156203/1044_Ley_Federal_del_Trabajo.pdf

Dirección Técnica de la Comisión Nacional de los Salarios Mínimos. (10 de septiembre de 2019). www.gob.mx. Obtenido de Efectos del salario mínimo en la Zona Libre de la Frontera: https://www.gob.mx/cms/uploads/attachment/fi le/494772/Efectos_del_salario_m_nimo_en_la_ Zona_Libre_de_la_Frontera_-

_Direcci_n_T_cnica_Conasami.pdf

INEGI. (24 de agosto de 2019). ENOE. Obtenido de INEGI: https://www.inegi.org.mx/programas/enoe/15y mas/default.html\#Tabulados

Resolución del H. Consejo de Representantes de la Comisión Nacional de los Salarios Mínimos que fija los salarios mínimos general y profesionales vigentes a partir del 1 de enero de 2019. (26 de 12 de 2018). Diario Ofricial de la Federación. 
Sistema de Administración Tributaria. (enero de 2019). Obtenido de http://omawww.sat.gob.mx/efrfn/Paginas/docu mentos/Presentacion_10012019.pdf

Yberry, M. (17 de diciembre de 2018). El aumento al salario mínimo, ¿tendrá consecuencias en México? Obtenido de Grupo Formula/Noticias/Finanzas/El aumento al salario mínimo, ¿tendrá consecuencias en México?:

https://www.radioformula.com.mx/noticias/fina nzas/20181217/aumento-salario-minimoconsecuencias-mexico-inflacion-twitter-2018/ 